FACTA UNIVERSITATIS

Series: Physical Education and Sport, Vol. 18, No 3, 2020, pp. 547 - 552

https://doi.org/10.22190/FUPES200709052K

Research article

\title{
THE ROLE OF FOOTBALL IN THE GREEK POST WAR SOCIETY THROUGH THE PRISM OF ANDREAS FRANGIAS' NOVEL PEOPLE AND HOUSES
}

\author{
UDC 796.332(495)(Andreas Frangjas)
}

\section{Tamara Kostić Pahnoglu, Tanja Cvetković}

Faculty of Philosophy, University of Niš, Niš, Serbia

\begin{abstract}
The aim of this paper is to examine the role of football in the lives of the novel's characters, in what way football is represented in Greek society in the early post war period, as well as to which extent this role is similar to the role of football in current society. It turned out that that role was extremely big, football was the only possibility for entertainment and relaxation, but also much more than that. Football matches were a place of gathering and strengthening of unity, an opportunity to belong to the community and to be accepted, but also a source of faith and hope for a better future and a place where the people could still win with the same zeal with which they looked at war victories. Nowadays, fan enthusiasm and belonging to a team are equally pronounced, but football now shares its social role from the post-war period with other sports that have become accessible to the public. The fact is, however, that no other sport has surpassed the love and passion for football.
\end{abstract}

Key words: Football, Literature, Greek Post-War Society

\section{INTRODUCTION}

Andreas Frangias is one of the most renowned Greek post-war novelists. He has published four novels that cover four decades of the Greek post-war society. His first novel, People and Houses, features a realistic description of life in one of Athens' suburbs immediately after World War II. The lives and destinies of numerous characters that inhabit the same neighborhood are intertwined in the novel and it is difficult to say who the protagonists are.

Received July 09, 2020/ Accepted December 03, 2020

Corresponding author: Tamara Kostić Pahnoglu

Faculty of Philosophy, University of Niš, Ćirila \& Metodija 2, 18105 Niš, Serbia

Phone: + 38118514312 •E-mail: harmonijanis@gmail.com

(C) 2020 by University of Niš, Serbia | Creative Commons License: CC BY-NC-ND 
Poverty and unemployment are the main common characteristics of most families. Difficult life circumstances have led to distance and isolation between the people, but there is still one thing that unites the inhabitants of the suburb every Sunday afternoon. It is football. During the whole week it is the only bright thought that they have except from work and money. They are looking forward to Sunday because they will go to the pitch, be together with friends and support the local team. If they have luck the team will win and there will be reason for joy in their lives. If the team loses they will be sad, but a new Sunday will bring new hope.

Many people today could identify with this description, but to what extent is the role of football in today's society equal to its role in the post-war period? Is this role more important now, or was it more important then? The realistic approach that Andreas Frangias takes in his novel, especially the relationship that the characters in the novel have to football, gives valuable information about the significance of football in the 1940s and it is our aim in this paper to compare it with the role that the football has today. Since the novel is fully realistic, we can consider it a faithful source of information.

The aim of this paper is to examine the role of football in the lives of the novel's characters, in what way football is represented in Greek society in the early post war period, as well as to which extent this role is similar to the role of football in current society.

\section{THEORETICAL CONSIDERATIONS OF THE PROBLEM}

Andreas Frangias is a rewarded and renowned author, but there are not many studies of his work. As far as the studies of his first novel are concerned, in some of them there are no references to football, while in some others it plays an important role. Our opinion is that its role is very important and in this paper we will examine whether it is so.

The plot of the novel starts on Sunday, which is the day for football. At the very beginning, on the fourth page of the novel, the reader gets acquainted with the importance of football. The author describes that the pitch is ready from the morning and that everyone who cares about the neighborhood says they have to win that day. Their team has lost several previous games and this time they have to win because if they lose again they will be considered fools. "We necessarily have to win", is a thought that we find without knowing to whom it belongs, but it seems to be the thought of the whole neighborhood (Frangias 2002:12). From the first pages of the novel it is made clear that indifference towards football is not tolerated. It is considered almost an insult to the whole neighborhood, as well as proof that something is wrong with the person who is indifferent.

Argiris, who could be considered the main character, even though it is difficult to decide whether there are protagonists or not, seemingly has different thoughts about winning. His opinion is that it is good to win at every game, but everything has its right time. Though, as the reader finds out later, his situation is quite similar to the neighborhood team's situation. He is unemployed and has failed several times to find a job. He is waiting for someone who had promised to help him and the statement that this time the neighborhood has to win the game is actually about him not being able to stand failing once more. He tries to comfort himself that it is not yet the right time, but deep inside he is desperate about not being able to earn money.

Argiris does not seem to pay much attention to football, and he explains the reason why. He believes that one must have a secure job in order to be able to care about games and championships (Frangias 2002:10). He feels very lonely, as if he is stigmatized in 
some way and expelled from the community. He sees that all the people who are going to watch the game have something in common, they have a job, and he has no right to go and try to be with them. The way he sees it, attending the football game means being accepted by the community and being a part of the whole. There are certainly many unemployed spectators, but Argiris' thoughts reflect his inner psychological state, his feeling that he is unworthy and that he is not allowed to have any enjoyment in his life. He believes that his unemployment is his stigma and that no one wants to be near him.

The arrival of the other team players further emphasizes Argiris' condition through the contradiction of his and their mood. The players are cheerful and self-confident, they are singing and waving their orange jerseys. Argiris' mind is dark and occupied with thoughts about the closed factory. Not only does he never sing, but he hardly ever talks, even to his wife. He remembers that a long time ago his wife used to sing, but those days are long gone.

It is obvious even from the first pages of the novel that football is equated with life and there are moments in which the reader cannot know whether the references in the text are about football or life in general. The author constantly mixes football with Argiris' condition and general situation in the afterwar society: "Things are difficult. If the big factory remains closed it does not mean that we have lost everything. The boys know how to play tough", claims the author. The football game equals the game of life. It is so intertwined with people and their lives that they use the same words and have the same thoughts about their own life and football.

The players of the local team are respected. They are considered brave and capable of controlling the situation. If they win, they are admired and adored. They are determined to win no matter the cost and they are devoted to their goal. It is obvious not only from the reactions on the pitch, but also in a scene when Kosmas, a young man from the neighborhood, talks to Georgia, Argiris wife. He says that someone has won and she comments that it was someone who did not get afraid, having in mind her husband who has not managed to find a job yet.

The best football player in the neighborhood is Ilias, but he is determined not to play anymore. He says that football is only for Sundays and that he wants to make something of his life. He does not like the pressure of people's expectations from him. He is the best and they all expect him always to win. He feels that they like him because he wins for them and not because of who he truly is. When he decides to stop playing, he is considered a traitor and no one wants to talk to him. Even his sister Olga expects him to be strong so that he can give her strength to fight her illness.

For the inhabitants of the neighborhood winning in football means that there is hope for a better future and the changes they are waiting for. Ilias knows that, he is completely aware that football is not just a game for them, and he cannot stand the responsibility of playing an important role in winning or losing. He says that the crowd was shouting "as if they were asking for something much bigger, more important than just a goal" (Frangias, 2002:189).

Football is used by the author even with the character who never went to the pitch. The character of Ilias sister Tasia is best reflected through her attitude towards football. She can either be proud because the crowd is shouting with joy, for Ilias has scored a goal, or she can say that he is worth nothing because he is only good at football and all he cares about is being supported by the crowd. Her attitudes are very changeable and depend on her mood.

Football also helps the author emphasize the false communication between the members of the family. Ilias is sad because neither of his sisters have ever come to see him play and support him. On the other hand, the sisters are both disappointed that he never took them with him to watch the game and support him. These misunderstandings about football 
reflect the loneliness and isolation that happens even inside the families. There is an obvious lack of communication between people and that leads to different bad feelings.

There is one point in the text where the author makes football very different from life in general. At that point he identifies the football game with holidays (Frangias, 2002:180). We cannot completely agree with that statement. If we compare all the references to football in the novel, comparing it with holidays is possible if we have in mind the people`s hope in the days before the game that they will have a good time, that that they will be together, that they will feel joy (but only if the team wins). These are the feelings that are usually expected from holidays. But what people do not expect from holidays and can expect from football in case of losing is stress, agony and the feeling of failure.

References to the role of football in Franigias` novel can be found only in the Greek reviews. Some of the reviewers give a big role to football, and some do not even mention it (all the reviewers who do mention it are named in this paper).

As Vangelis Hatzivasileiou emphasizes, the Sunday football games are the only way out of the everyday pressure for the inhabitants, even if it is just an illusion that they are out of the everyday reality when they are on the pitch (Hatzivasileiou, 2002: 98). People carry their worries everywhere and they just seemingly get rid of them while they are watching football. If anything goes wrong in the game, they are immediately reminded of their problems. But it might be relieving to be able to blame someone else for failure and not yourself.

Takis Karvelis agrees with Hatzivasileiou`s statement and adds that it is the only way out of everyday problems in a difficult life in which there is no communication between people (Karvelis, 1988:12).

A deeper insight in the importance of football is given by Kostas Papageorgiou (Papageorgiou, 2000). Since the novel was written about the period just after the Second World War, he compares the heroes of the football game with the heroes from the past war. Papageorgiou believes that the color of the clothes that the players wear, the blue color of the Greek flag, tends to make this story national, not just about that concrete neighborhood. After four years of war, people suddenly found themselves in the peace they were fighting for, but it was not as they expected and hoped for. They are poor, their life is meaningless and they cannot remember how to be cheerful again. Football gives them an aim higher than just providing food. Football champions are equated with the ethnical heroes and their achievements become legendary. The pitch is almost a holy place, like a church, and the importance of victory in the game is abnormal, a matter of life and death. The pitch does not have regular dimensions, it actually has no borders, it covers the whole neighborhood and goes even farther. The results are of extreme importance for the inhabitants, as if their lives depend on them.

Football is a substitute for the destroyed faith in something bigger. This faith is destroyed for the people of the neighborhood, but they represent the whole nation. They have to win in the game, because it seems to be the only victory that they can achieve and that could make them feel worthy and good. Many inhabitants are unemployed and that makes them feel unworthy. Football is the only light in their lives in that period.

If a man wants to be accepted in the society, he must show interest in football, he must talk about it, feel happy if the team wins and sad if it loses. The rejection that Ilias meets from all the people is equal to the rejection he would get as a traitor in the war.

Papageorgiou almost poetically compares the pitch to an oasis, and a colorful island in the sea of problems that are constantly present and almost impossible to solve. 
Babis Klaris emphasizes that the two main themes in the novel are unemployment and football, as if those were the only contents of the lives of the people from the neighborhood (Klaris, 1956). Karvelis agrees with the important role of football and notices that the only things people are talking about are work, the factory and football (Karvelis, 1988: 12).

What Dimitris Kokoris claims about the role of football is that it is not a way for people to cover up their problems, but it reflects their problems like a mirror. A very important role of football is to unite people who are divided by unemployment - those who work do not seem to have much in common with those who do not. The unemployed are generally equated with unworthiness, while during the football game they are all the same (Kokoris, 2009: 56).

As he states, the fact that the main character of the novel, Argiris, is completely out of football is quite controversial. He does not go to watch the games, he does not talk about them, and does not even think about them. Ilias' rejection is really extreme. He asks the man he does not even know to light a cigarette, but the man refuses to let him do it. He explains that he does not want to know him and that he does not exist for them anymore. When Nikos, a young new player, plays well, people say that he saved the team, but it seems as if he has saved the whole community. That is because he saved the hope for a bright and optimistic future.

Space plays an important role in the novel. Many more details about the role of space

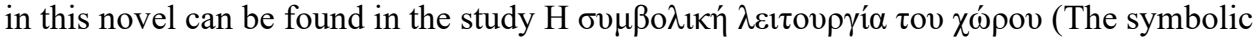
function of space) by Eri Stavropoulou (2001).

The people are mostly confined to their houses or the factory. Going out to the pitch, even though it is a closed space again, in some way reflects that people still have the power to do something unusual in their lives, to do something because they want to, not because they have to. The game of football is actually equated with freedom and with the possibility of choice. In the poor neighborhoods of the post war society, it is probably the only thing in the people`s lives that allows them to feel like free human beings.

\section{CONCLUSION}

As shown above, football is not only a tool used by the author to construct the characters and the plot, but a very important component of life in the Greek post-war society. It is very important in today`s society as well, but not as important as it was then.

The main reason for that is the fact that today`s society offers many other opportunities for relaxation, fun and avoiding the everyday routine and problems, whereas in the post-war years the opportunities were limited to football.

What has not changed is the people's need to have something that can occupy their thoughts and make them feel part of a whole, make them feel accepted and not alone.

The football players are still heroes, they are respected and adored. The decision that Ilias made to leave football and go to school would be unusual today, because today`s good players earn a lot of money. Their status has changed from amateurs to professionals.

We tend to say that today football is the most important unimportant thing in life, but the impression from the novel is that in those years it was not so unimportant. It was a very important component of everyday life and in many ways the important things from life were mirrored on and around the pitch. 
Nowadays people have many choices as to which games and matches to go to, but still the magic of football attracts the majority of spectators.

It offers, today as before, a feeling of unity, of breaking the barriers, of overcoming personal abilities, of being capable to change changes, of advancing in life, of being stronger, braver and, usually, happier than in the everyday routine. The football was and still is the symbol and the proof of the possibility to create the life you really want and from that point of view it was and still is necessary in every society.

\section{REFERENCES}

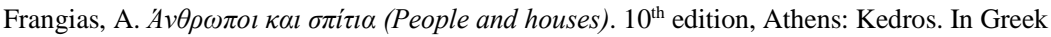

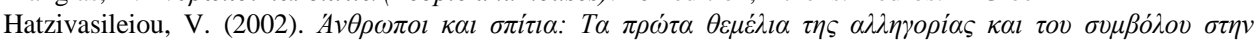

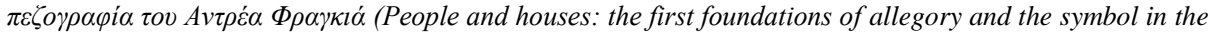
fiction of Andreas Frangias). (pp. 97-100). Diavazo. In Greek

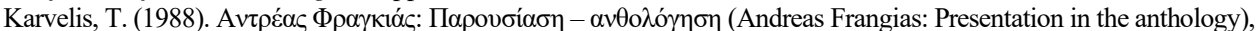
H $\mu \varepsilon \tau \alpha \pi о \lambda \varepsilon \mu \imath \kappa \eta ́ ~ \pi \varepsilon \zeta o \gamma \rho \alpha \varphi i ́ \alpha$, Vol. 8 (The afterwar fiction, Vol. 8), (pp. 8-29), Athens: Sokolis. In Greek

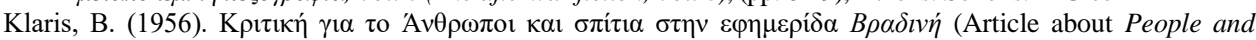
houses in the newspaper Vradini). Athens: 1956. In Greek

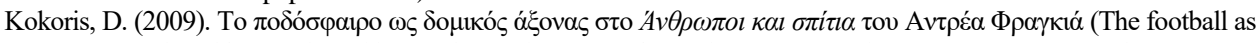
a structural axel in People and houses by Andreas Frangias). Themata Logotehnias, 40, 55-64. In Greek

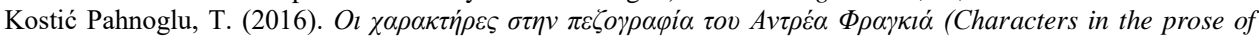
Andreas Frangias). Doctoral thesis. Athens, National and Kapodistrian University of Athens. In Greek

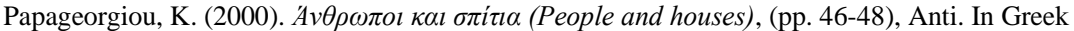

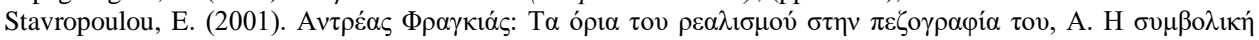

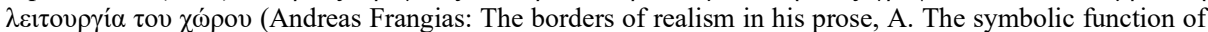

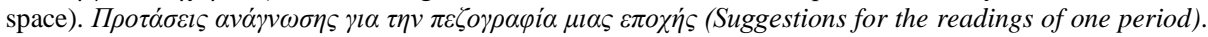
Athens: Sokolis. In Greek

\section{ULOGA FUDBALA U GRČKOM POSLERATNOM DRUŠTVU KROZ PRIZMU ROMANA LJUDI I KUĆE ANDREASA FRANGJASA}

Cilj rada bio je da se ispita uloga fudbala u životu likova romana, mere i načina zastupljenosti fudbala u grčkom društvu u ranom posleratnom periodu, kao $i$ u kojoj meri je uloga fudbala $u$ grčkom posleratnom društvu slična ulozi u sadašnjem društvu. Pokazalo se da je ta uloga bila izuzetno velika, fudbal je bio jedina mogućnost razonode $i$ opuštanja, ali i mnogo više od toga. Fudbalske utakmice su bile mesto okupljanja i jačanja zajedništva, mogućnot da se pripada zajednici $i$ bude prihvaćen, ali i izvor vere $i$ nade u bolju budućnost $i$ mesto na kojem se $i$ dalje moglo pobeđivati sa jednakim žarom sa kojim se gledalo na pobede u ratu. U današnje vreme navijački žar i pripadnost timu jednako su izraženi, ali svoju društvenu ulogu iz posleratnog perioda fudbal sada deli sa drugim sportovima koji su postali pristupačni publici. Činjenica je, međutim, da ljubav i strast prema fudbalu ni jedan drugi sport nije nadmašio.

Ključne reči: fudbal, Andreas Frangjas, grčko posleratno društvo 